\title{
The significance of the FTO gene on weight gain and body composition in young Swedish women with severe anorexia nervosa: a three-year follow-up study
}

Anna Svedlund(New Corresponding Author) ( $\square$ anna.svedlund@vgregion.se ) https://orcid.org/0000-0001-5086-8009

Bojan Tubic

Goteborgs universitet Sahlgrenska Akademin

Anders Elfvin(Former Corresponding Author)

Goteborgs universitet Institutionen for kliniska vetenskaper https://orcid.org/0000-0002-1912-9563

Per Magnusson

Linkopings universitet

Diana Swolin-Eide

Goteborgs universitet Institutionen for kliniska vetenskaper

\section{Research article}

Keywords: Eating disorder; Fat mass and obesity-associated gene; Body mass index; Nutrition therapy; Physical activity

Posted Date: May 4th, 2020

DOI: https://doi.org/10.21203/rs.2.22865/v2

License: (c) (i) This work is licensed under a Creative Commons Attribution 4.0 International License.

Read Full License 
The authors have withdrawn this preprint from Research Square 